\title{
A REVIEW ON WASTE COOKING OIL BIODIESEL AS A VIABLE FUEL FOR DIESEL ENGINES: EXISTING CONCEPTS, EMERGING TRENDS AND FUTURE PROSPECTS
}

\section{HILTON MAVERENGO \& PROFESSOR FREDDIE L. INAMBAO*}

Department of Mechanical Engineering, University of KwaZulu-Natal, Durban, South Africa

\begin{abstract}
The world is in an irreversible process of switching to alternative fuel sources for diesel engines. This has been necessitated by accelerated depletion of fossil diesel resources coupled with the detrimental impact of exhaust emissions on the environment. Biodiesel is a standout amongst other possible fuel options for diesel engines that have been discussed in the literature. Biodiesel is regarded as a clean source of fuel because its combustion results in a decrease in most harmful emissions when compared with fossil diesel fuels. However, some feedstocks for biodiesel are not feasible due to the exorbitant cost of acquisition and their negative impact on food supply channels. A switch to waste cooking oil (WCO) is viewed as the most encouraging option for biodiesel feedstock despite its disadvantages, like its high free fatty acid (FFA) and water content. In this paper, existing concepts used for WCO biodiesel production process in regard to feedstock pre-treatment, production technologies and purifications methods are analysed, highlighting the merits and demerits of available options. Furthermore, emerging trends and prospects of WCO biodiesel production technologies are presented.
\end{abstract}

KEYWORDS: Waste Cooking Oil Biodiesel, Pre-Treatment, Production Technologies \& Purification

Received: Jun 13, 2021; Accepted: Jul 03, 2021; Published: Aug 09, 2021; Paper Id.: IJMPERDOCT20212

\section{NOMENCLATURE AND ABBREVIATIONS}

\begin{tabular}{|ll|lc|}
\hline $\mathrm{AL}_{2} \mathrm{O}_{3}$ & \multicolumn{1}{|c|}{ Aluminum oxide } & $\mathrm{NOx}$ & Nitrogen oxide \\
$\mathrm{ASTM}$ & American Society for Testing and Materials & $\mathrm{N}_{2}$ & Nitrogen gas \\
$\mathrm{BD}$ & Biodiesel & $\mathrm{H}_{2} \mathrm{SO}_{4}$ & Sulphuric acid \\
$\mathrm{CH} 3 \mathrm{ONa}$ & Sodium methoxide & Waste cooking oil \\
$\mathrm{FD}$ & Fossil diesel & & \\
$\mathrm{FFA}$ & Free fatty acid & & \\
$\mathrm{KOH}$ & Potassium hydroxide & & \\
$\mathrm{NaOH}$ & Sodium hydroxide & \\
\hline
\end{tabular}

\section{INTRODUCTION}

With expanding population and modernization, the world is being confronted with a challenge requiring both higher energy generation coupled with reduction in emission of toxic gasses to the atmosphere. Population increase is 
stimulating higher energy utilisation bringing about increased generation of greenhouse gas emissions (Franco et al., 2017). Petroleum products are the main energy resources utilized in the automotive industry. However, combustion of petroleum products results in emission of toxic gasses which are the main causes of global warming and air pollution which are posing a risk to the environment and human health (Mofijur et al., 2014). These drawbacks of petroleum products have necessitated the search for renewable fuel resources which are nontoxic and compatible with current automotive engines; biodiesel has emerged as the best option available especially for transportation of heavy goods. This is because biodiesel fuel properties make it suitable for blending with fossil diesel in various proportions (Nisar et al., 2018). Furthermore, pure biodiesel fuel can be utilised in diesel engines with little or no engine modification (R Mohsin et al, 2014). Biodiesel is a renewable, nontoxic, highly biodegradable fuel resource (Roy et al., 2014). Biodiesel is a feasible and inexhaustible fuel resource that is delivered from an assortment of feedstocks, like vegetable oils, animal fats, waste cooking oil, algal oil, among others (Costa et al. 2018). Biodiesel is created through the transesterification of fatty acid containing substances with a short-chain alcohol under the influence of a catalyst (Iso et al., 2001). Several investigations have revealed that the utilization of biodiesel decreases most of the general discharges from a diesel engine. Despite decreases in most emission gases, the usage of biodiesel is reported to cause increased emission of nitrogen oxides (NOx), an issue which is also slowing its adoption (Chen et al., 2018). In general, there are four significant classifications of feed stocks utilized as raw materials for the biodiesel creation based on sustainability, namely, $1^{\text {st }}$ generation (edible feedstocks) such as sugars and grains, $2^{\text {nd }}$ generation (non-edible) feedstocks, $3^{\text {rd }}$ generation (waste-based feedstocks) and $4^{\text {th }}$ generation (genetically engineered crops) of which the issues related to each subgroup are shown in figure 1.

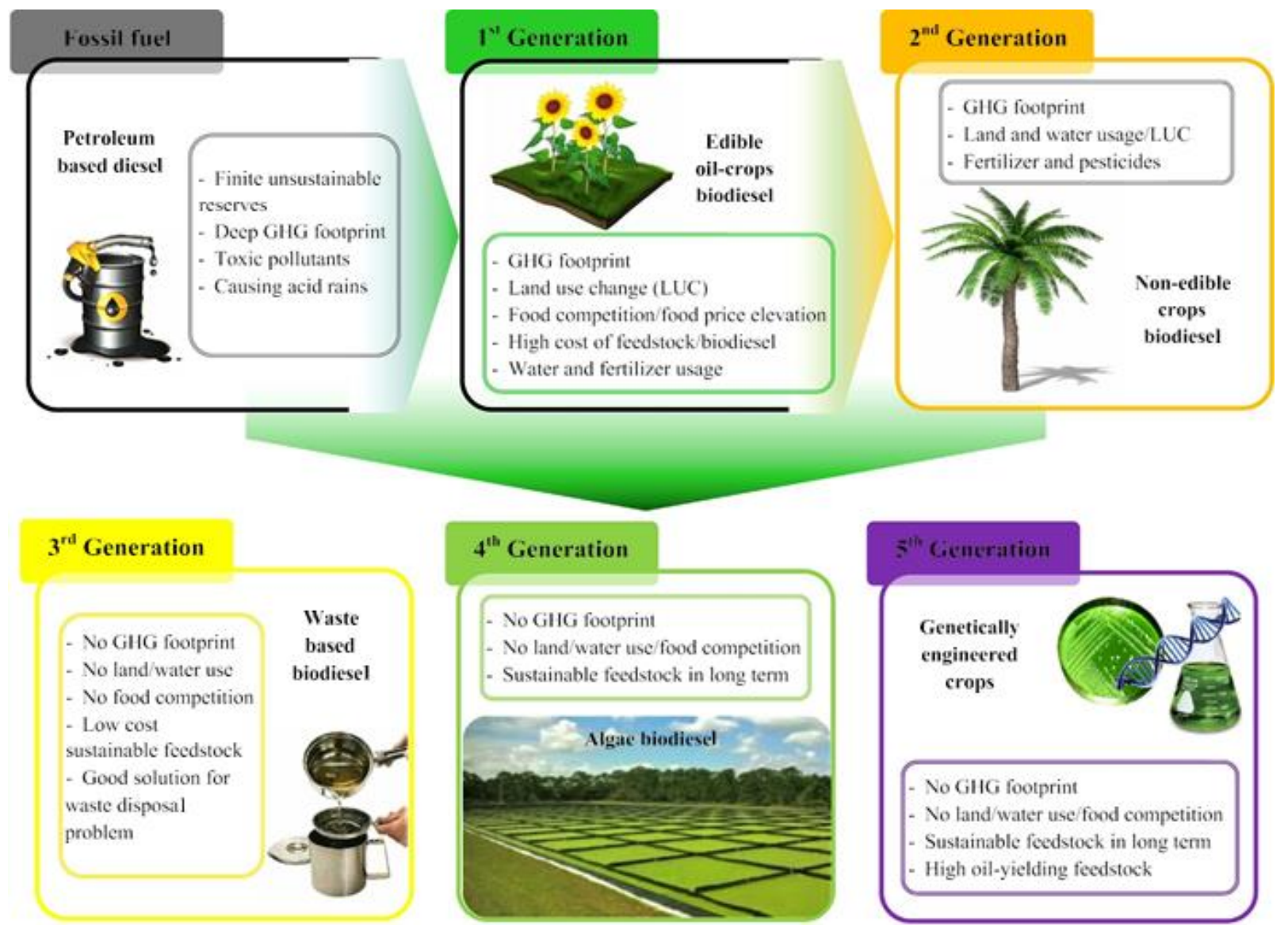

Figure 1: Classification of Biodiesel Feedstocks (Hajjari et al. 2017). 
Deployment of biodiesel has been hampered by exorbitant feedstock costs. The cost of biodiesel production has been influenced mostly by cost of feedstock which is almost $74 \%$ of total production cost (de Jong et al. 2017), as illustrated in Figure 2. Currently, edible feedstocks has been most used for the production of biodiesel (more than 95\%) (Pinzi et al., 2014). However, the use of food-based edible feedstock for biodiesel production has brought about a food versus fuel debate because of the related increase in food costs and land use changes as more land is allocated to fuel feedstocks. Diverting food resources to fuel production results in a higher return on investment compared to its food resources for consumption (Che et al. 2012). Utilisation of waste cooking oil (WCO) for biodiesel production is not only beneficial to fuel production but will also solve its disposal challenge. Uncontrolled disposal of WCO causes soil and water pollution as well as water system blockages. Furthermore, utilizing waste and nonedible oils in biodiesel creation will also help to resolve the biodiesel contest with food utilization.

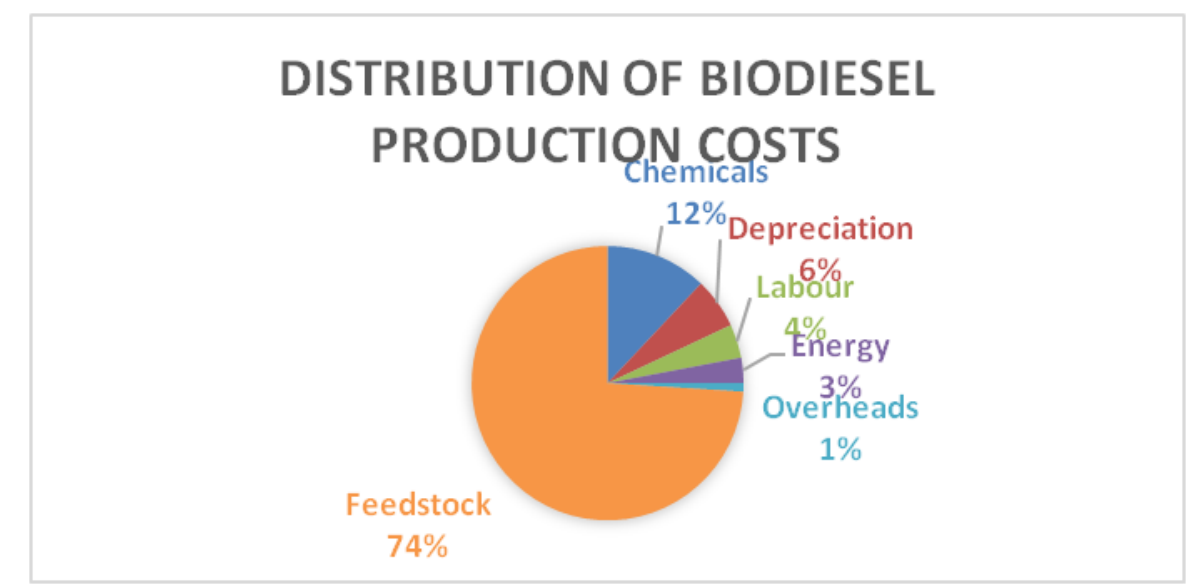

Figure 2: Breakdown of Biodiesel Production Costs (de Jong et al., 2017).

The above analysis reveals that WCO can be a viable source of feedstock for biodiesel production because it has many environmental benefits. Based on that a review is hereby presented to analyse WCO feedstocks, its characteristics, biodiesel production technologies and methods of purification to inform future research endeavours on this subject.

\section{WASTE COOKING OIL: A POTENTIAL FEEDSTOCK FOR BIODIESEL FUEL}

Huge amounts of WCOs are accessible throughout South Africa. WCO is produced by domestic homes and by industry. Increased human population will result in increased food consumption, leading to higher WCO generation. South Africa alone produces more than 600000 tons of waste cooking oil each year (Hamze et al., 2015). However, this abundant feedstock resource was ignored when the Department of Energy announced its Sustainable Development strategy (Brent et al., 2009). WCO can be gathered from food producers and deep fryers, for example, potato handling plants and snack food production lines, fast foods, cafés, catering businesses and from domestic households, where it is used for food preparation.

WCO, which is generally wasted, has emerged as the most viable and economic source for biodiesel since it can be acquired at low cost in comparison to all other feedstocks. The cost of feedstock has been identified as the main barrier to accelerated biodiesel deployment hence a switch to WCO will improve the financial viability of its creation. WCO produced in Europe, North America and Asia is around 16.6 million tons in a year, which can mathematically satisfy total oil demand for fuel generation (Azócar et al., 2010). However, there are some disadvantages in utilizing WCO for the creation of biodiesel because it contains contaminants such as free unsaturated fat (FFA) and water. These need to be 
eliminated before transesterification due to their unfavourable impact on the engine fuel supply components.

\subsection{Characteristics of Waste Cooking Oil and its Feedstock Potential}

Given the plenitude and cost of feedstock, WCO has emerged as the number one candidate for biodiesel production. The properties of WCO are marginally not the same as those of virgin oils due to the changes that occur as a result of cooking or frying. Frying is a process that involves the exposure of food in oils or fats to high temperatures ranging from $160{ }^{\circ} \mathrm{C}$ to $200{ }^{\circ} \mathrm{C}$. This process is performed in the presence of moisture, antioxidants, and oxygen (Safari et al., 2018). This process results in changes to the chemical and physical properties through hydrolysis, polymerization, and oxidation (Lam, 2010). Most WCO contains water content ranging from $0.5 \%$ to $55 \%$ and acid values of around $193 \mathrm{mg}-\mathrm{KOH} / \mathrm{g}$-oil. Higher water content causes hydrolysis of the oil while higher FFA content influences formation of soaps, all which reduce oil quality and biodiesel yield. Oxidation processes entail conversion of oil into other compounds in the presence of oxygen. Compounds formed include peroxides, ketones, and aldehydes. The oxidation process is affected by the type of oil, oxygen availability and duration of oil exposure to heat. Hydrolysis defines a process in which the oil is converted into other volatile compounds due to reaction with water, as depicted in Figure 3. A lower measure of free unsaturated fats causes lower oxidation and hydrolysis in the transesterification reaction (Refaat et al., 2008). Addition of a base catalyst results in the FFAs forming soap and water. The soap formation reaction is shown in Figure 4. This implies that before the transesterification process, water and contaminants must be eliminated from the WCO to supress soap formation. These processes transform fuel properties from those of virgin oil, hence the main WCO fuel properties are shown in Table 1. Many standards are used to qualify biodiesel derived from various feedstocks and these standards are summarised in Table 2.

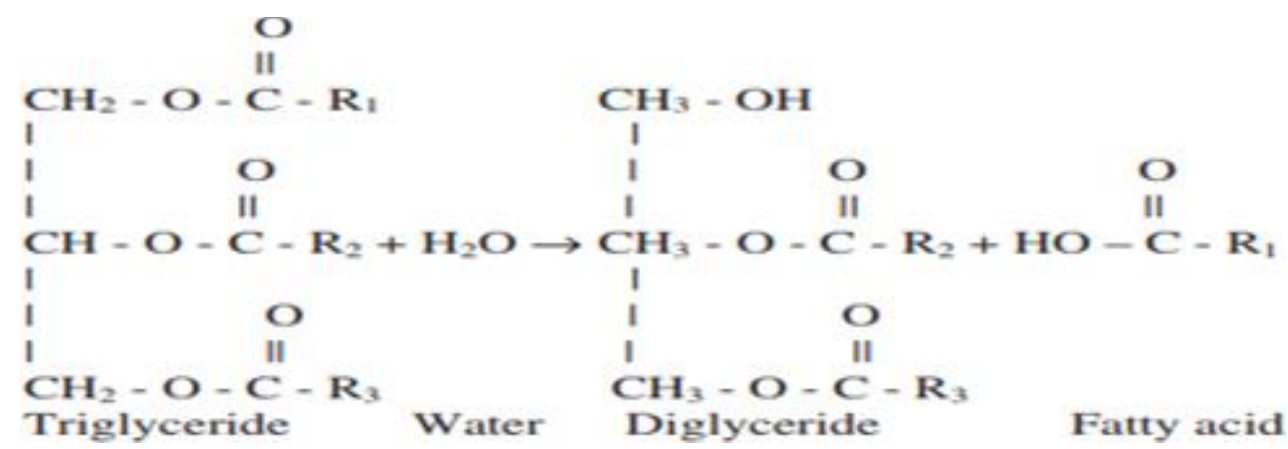

Figure 3: Hydrolysis Process (Farooq et al., 2015).

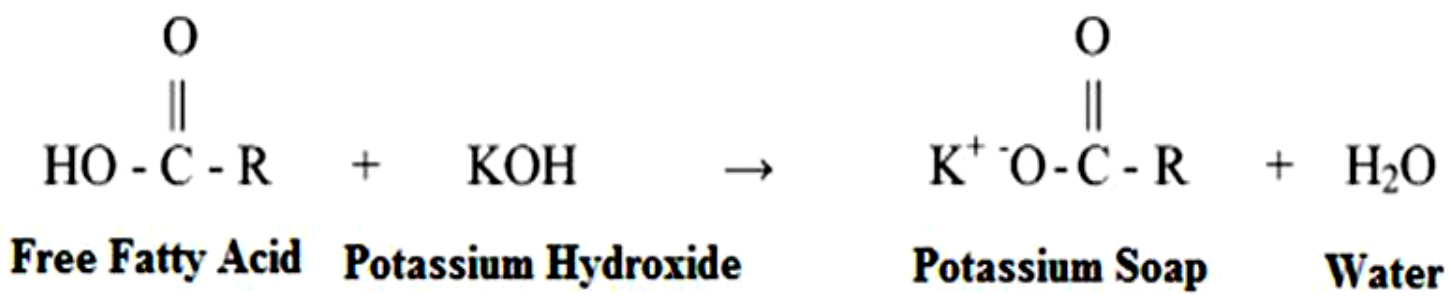

Figure 4: Soap Formation Process. 
Table 1: Properties of WCO

\begin{tabular}{|l|c|}
\hline \multicolumn{1}{|c|}{ Property } & Value \\
\hline Density $\left(\mathrm{g} / \mathrm{cm}^{3}\right)$ & $0.91-0.924$ \\
\hline $\begin{array}{l}\text { Kinematic Viscosity } \\
\left(40^{\circ} \mathrm{C}\right)\left(\mathrm{mm}^{2} / \mathrm{s}\right)\end{array}$ & $36.4-42$ \\
\hline Saponification & $188.2-207$ \\
\hline Acid value & $1.32-3.6$ \\
\hline Iodine number & $83-141.5$ \\
\hline
\end{tabular}

Table 2: South African and International Biodiesel Standards (Kitani 1999).

\begin{tabular}{|c|c|c|c|c|c|}
\hline $\begin{array}{l}\text { Specification or } \\
\text { property }\end{array}$ & Units & $\begin{array}{l}\text { Europe } \\
14214)\end{array}$ & $\begin{array}{l}\text { USA(ASTM } \\
6751-08)\end{array}$ & $\begin{array}{l}\text { South Africa } \\
\text { (SANS 1935) }\end{array}$ & $\begin{array}{l}\text { South African } \\
\text { test method }\end{array}$ \\
\hline 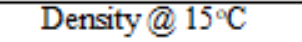 & $\mathrm{kg} / \mathrm{m}^{3}$ & $0.86-0.90$ & Report & $0.86-0.90$ & ISO 3675 \\
\hline Viscosity@40 $\mathrm{C}$ & $\mathrm{mm}^{2} / \mathrm{s}$ & $3.5-5.0$ & $1.9-6.0$ & $3.5-5.0$ & ISO 3104 \\
\hline Distillation T90 & ${ }^{\circ} \mathrm{C}$ & $\mathrm{n} / \mathrm{a}$ & 360 & $\mathrm{n} / \mathrm{a}$ & - \\
\hline Flashpoint & ${ }^{\circ} \mathrm{C}$ & $120 \mathrm{~min}$ & $130 / 93 \mathrm{~min}$ & $120 \mathrm{~min}$ & ISO 3679 \\
\hline Sulphur & $\mathrm{mg} / \mathrm{kg}$ & $10.0 \mathrm{max}$ & $15 \max$ & $10 \max$ & ISO 20846 \\
\hline $10 \%$ Carbon residue & $\%$ mass & $0.30 \mathrm{max}$ & $\mathrm{n} / \mathrm{a}$ & $0.3 \max$ & $\begin{array}{l}\text { ASTM } \\
\text { D1160 }\end{array}$ \\
\hline $100 \%$ Carbon residue & $\%$ mass & $\mathrm{n} / \mathrm{a}$ & $0.050 \max$ & $\mathrm{n} / \mathrm{a}$ & - \\
\hline Sulphated Ash & $\%$ mass & $0.02 \max$ & $0.020 \max$ & $0.02 \max$ & ISO 3987 \\
\hline Water and sediment & $\mathrm{mg} / \mathrm{kg}$ & $500 \max$ & $500 \max$ & $500 \max$ & ISO 12937 \\
\hline Total contamination & $\mathrm{mg} / \mathrm{kg}$ & $24 \max$ & $\mathrm{n} / \mathrm{a}$ & $24 \max$ & EN 12662 \\
\hline Cu strip corrosion & $3 \mathrm{~h} a 50^{\circ} \mathrm{C}$ & Class 1 max & No. $3 \max$ & Class 1 max & ISO 2160 \\
\hline Oxidation stability & $\mathrm{h} @ 110^{\circ} \mathrm{C}$ & $6 \mathrm{~min}$ & $3.0 \mathrm{~min}$ & $6 \mathrm{~min}$ & EN 14112 \\
\hline Cetane number & - & $51.0 \mathrm{~min}$ & $47 \mathrm{~min}$ & $51 \mathrm{~min}$ & ISO 5165 \\
\hline Linolenic acid & $\%$ mass & $12.0 \mathrm{max}$ & $\mathrm{n} / \mathrm{a}$ & $12 \max$ & EN 14103 \\
\hline Acid value & $\mathrm{mgKOH} / \mathrm{g}$ & $0.50 \mathrm{max}$ & $0.50 \max$ & $0.50 \max$ & EN 14104 \\
\hline Methanol & $\%$ mass & $0.20 \mathrm{max}$ & $0.2 \max$ & $0.20 \max$ & EN 14110 \\
\hline Ester content & $\%$ mass & $96.5 \mathrm{~min}$ & $\mathrm{n} / \mathrm{a}$ & $96.5 \mathrm{~min}$ & EN 14103 \\
\hline Triglyceride & \%mass & $0.20 \mathrm{max}$ & $\mathrm{n} / \mathrm{a}$ & $0.2 \max$ & EN 14105 \\
\hline Total gycerol & $\%$ mass & $0.25 \mathrm{max}$ & $0.24 \max$ & $0.25 \max$ & EN 14105 \\
\hline Iodine num ber & $\mathrm{gI}_{2} / 100 \mathrm{~g}$ & $120 \max$ & $\mathrm{n} / \mathrm{a}$ & $140 \max$ & EN 14111 \\
\hline Phosphorus & $\mathrm{mg} / \mathrm{kg}$ & $10.0 \max$ & $10 \max$ & $10 \max$ & EN 14107 \\
\hline Cloud point & & Report on request & Report & Report on request & - \\
\hline
\end{tabular}

\subsection{Pre-Treatment of Waste Cooking Oil Feedstocks}

High temperature cooking/frying results in formation of several compounds which lead to a high rate of FFAs which impacts on biodiesel formation (Mittelbach and Remschmidt, 2005). Pre-treatment involves the reduction of FFAs in the oil to under $1 \mathrm{mg} \mathrm{KOH} / \mathrm{g}$ equivalent and reduction of water to acceptable levels depending on standards being followed in fuel preparation. The availability of excessive FFAs make catalysts inactive thereby reducing the biodiesel conversion process. The deacidification process can be undertaken by adding a base catalyst, for example, $\mathrm{NaOH}$, which reacts with FFA resulting in soap formation (Tyson et al., 2004). Pre-treatment of WCO before base catalysed transesterification is done because the catalyst is sensitive to water and FFA content in feedstock (Marchetti et al., 2007). Different sorts of pretreatment strategies are utilized for WCO purification, for example, steam infusion (Lertsathapornsuk et al., 2005), vacuum filtration and column chromatography (Lee et al., 2002), balance, film vacuum cleaning (Cvengroš \& Cvengrošová 2004) and vacuum filtration (Dias et al., 2008). An investigation performed by Shimada Y, et al., (200) using steam and sedimentation of WCO revealed a significant reduction in the hydrolysis process and FFA content. A reduction of water 
content from $14 \%$ to $0.4 \%$ was noted as well as a reduction in FFA from 6.3 wt $\%$ to 4.3 wt $\%$. Saifuddin N, et al., (2004) suggests that filtration of the oil coupled to microwave drying can remove most of the suspended substances related to the feedstock. Centrifugation has also been noted to be a viable process for pre-treatment of WCO. However, all these abovementioned processes result in an increase in biodiesel production cost, hence a more suitable and cost-effective method must be selected for each feedstock.

\section{PARAMETERS INFLUENTIAL TO TRANSESTERIFICATION REACTION}

\subsection{Type of Catalyst Used}

Transesterification entails production of biodiesel using vegetable oil and an alcohol (methanol or ethanol), under influence of a catalyst. Several versions of catalysts have been used to date and these can be alkali, acidic or enzyme based, although enzyme derived catalysts are limited by the need for rigorous conditions which suppresses their commercial usage. The process to be followed in WCO biodiesel production is primarily based on the amounts of FFAs and water contained by the feedstock oil. Various catalysts that can be utilised for WCO biodiesel production are discussed in subsequent sections and summarised in table 3.

Table 3: Analyses of Transesterification Processes (Gog et al., 2012)

\begin{tabular}{|l|l|l|l|}
\hline \multicolumn{1}{|c|}{ Parameter } & \multicolumn{1}{|c|}{ Base Catalysis } & \multicolumn{1}{c|}{ Acid Catalysis } & \multicolumn{1}{c|}{ Enzymatic Catalysis } \\
\hline FFA content & Result in soap formation & FFA converted to methyl esters & $\begin{array}{l}\text { FFA is converted to methyl } \\
\text { esters }\end{array}$ \\
\hline Water content & $\begin{array}{l}\text { Promote hydrolysis process } \\
\text { which lead to soap formation }\end{array}$ & Deactivates the acid catalyst & $\begin{array}{l}\text { Not affected by water } \\
\text { content }\end{array}$ \\
\hline Yield & High $>95 \%$ & High $>90 \%$ & High $>90 \%$ \\
\hline $\begin{array}{l}\text { Rate of } \\
\text { reaction }\end{array}$ & High & Lower than base catalysed & Lower acid/base catalysed \\
\hline $\begin{array}{l}\text { Glycerol } \\
\text { retrieval }\end{array}$ & $\begin{array}{l}\text { Difficult, poor quality of } \\
\text { glycerol }\end{array}$ & $\begin{array}{l}\text { Difficult resulting in poor } \\
\text { quality of glycerol }\end{array}$ & \\
\hline $\begin{array}{l}\text { Catalyst } \\
\text { recovery and } \\
\text { reuse }\end{array}$ & $\begin{array}{l}\text { Complex, the catalyst reacts } \\
\text { with acid to form salts and } \\
\text { water, not reusable }\end{array}$ & $\begin{array}{l}\text { Complex, the catalyst ends up } \\
\text { in end products. Not reusable }\end{array}$ & Easy. Can be reused \\
\hline Cost of catalyst & Low & Low & High \\
\hline
\end{tabular}

\subsubsection{Base Catalysed Transesterification}

Base catalysed transesterification processes entail reacting glyceride with an alcohol to form an ester and glycerol in the presence of a base catalyst (Rashid et al., 2008). Base-catalysed transesterification is the most widely recognized method among other transesterification processes since it is the least expensive, simplest, and quickest method which uses the least preparation steps (Varanda et al., 2011). The most widely recognized catalysts utilized in transesterification are potassium hydroxide $(\mathrm{KOH})$ and sodium hydroxide $(\mathrm{NaOH}) . \mathrm{KOH}$ is favoured since its usage suppresses soap formation. Furthermore, the soap formed from the $\mathrm{KOH}$ catalysed process is easier to separate from biodiesel fuel. Base transesterification can result in very high biodiesel yields of up to $95 \%$ yield at moderate temperatures, pressure, and reaction time (Leung \& Guo, 2006). However, base catalysed processes are affected by high water and FFA contents which are found in WCO feedstock. This process is also impacted by other contaminants such as dirt, solid particles and quality of reactions which makes treating of feedstock before the reaction necessary (Alptekin et al., 2011). Hence, base transesterification is a desirable method when the feedstock contains FFAs under $1 \mathrm{wt}$. \%. This subsequently means that base catalysis is not initially feasible on WCO which contains higher FFA in > $5 \%$ (Xia, 2017). Thusly, direct soluble 
catalysed transesterification process utilizing base catalyses is not advised hence pre-treatment techniques including steam refining, extraction by liquor, and corrosive synergist esterification are undertaken to lower the FFA to below $1 \%$ (Günay et al., 2019). However, most of the biodiesel plants at present are utilizing homogeneous soluble base catalyses, i.e., sodium or potassium hydroxides, carbonates or alkoxides since the utilization of these catalyses are financially viable compared to heterogeneous catalyses (Yin et al., 2008). Base catalysed transesterification is influenced by the reaction temperature. As the temperature expands, the rate of reaction increases which increases the biodiesel conversion process. However excessive temperatures promote the saponification process which is more visible the longer the process (Ferrari et al., 2011). The reaction temperature ought to be maintained below alcohol boiling point to deter it from vaporizing, although this will reduce biodiesel production. For optimal biodiesel production, reaction temperatures must be maintained in the range of $40{ }^{\circ} \mathrm{C}$ and $60{ }^{\circ} \mathrm{C}(\mathrm{Li}$ et al., 2013). The process is shown in figure 5 .

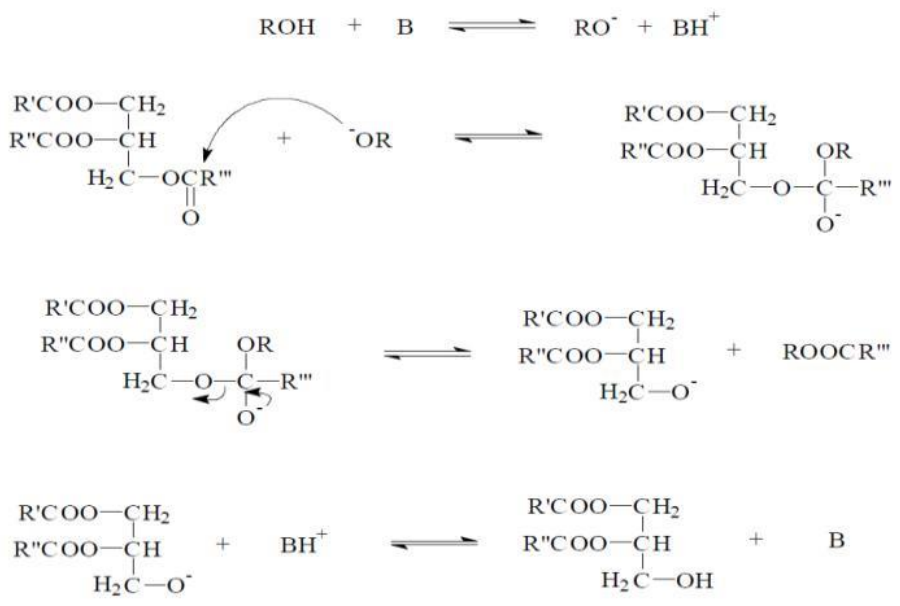

Figure 5: Homogenous base Catalysis Mechanism.

Table 4: Homogenous Catalysed Transesterification.

\begin{tabular}{|c|c|c|c|c|c|c|c|}
\hline Ref. & Oil & $\begin{array}{c}\text { Used } \\
\text { Catalyst }\end{array}$ & $\begin{array}{c}\text { Percentage } \\
\text { of catalyst }\end{array}$ & $\begin{array}{c}\text { Alcohol } \\
\text { wt. } \%\end{array}$ & $\begin{array}{l}\text { Oil to alcohol } \\
\text { molar ratio }\end{array}$ & $\begin{array}{l}\text { Reaction } \\
\text { conditions }\end{array}$ & $\begin{array}{c}\text { Ester } \\
\text { yield } \\
(\%)\end{array}$ \\
\hline $\begin{array}{l}\text { Wang et al. } \\
(2006)\end{array}$ & WCO & $\begin{array}{l}\text { Acid } \\
\text { (H2SO4) }\end{array}$ & 4 & Methanol & 01:20 & $95 \mathrm{LC}, 10 \mathrm{~h}$ & - \\
\hline $\begin{array}{l}\text { (Karmee \& } \\
\text { Chadha (2005) }\end{array}$ & $\begin{array}{l}\text { Pongamia } \\
\text { pinnata }\end{array}$ & $\begin{array}{l}\text { Base } \\
(\mathrm{KOH})\end{array}$ & 1 & Methanol & 01:10 & $\begin{array}{l}60 \mathrm{LC}, 1.5 \\
\mathrm{~h}\end{array}$ & - \\
\hline $\begin{array}{l}\text { Rashid et al., } \\
(2008)\end{array}$ & $\begin{array}{l}\text { Rapeseed } \\
\text { oil }\end{array}$ & $\begin{array}{l}\text { Base } \\
(\mathrm{KOH})\end{array}$ & 1 & Methanol & 01:06 & $\begin{array}{l}65 \mathrm{LC}, 2 \\
\mathrm{~h}, 600 \mathrm{rpm} \\
\end{array}$ & 96 \\
\hline $\begin{array}{l}\text { (Rashid et al. } \\
(2008)\end{array}$ & $\begin{array}{l}\text { Sunflowe } \\
\text { r oil }\end{array}$ & $\begin{array}{l}\text { Base } \\
(\mathrm{NaOH})\end{array}$ & 1 & Methanol & 01:06 & $\begin{array}{l}60 \mathrm{LC}, 2 \\
\mathrm{~h}, 600 \mathrm{rpm} \\
\end{array}$ & 97.1 \\
\hline \multirow[t]{3}{*}{$\begin{array}{l}\text { Leung \& Guo } \\
(2006)\end{array}$} & $\begin{array}{l}\text { Used } \\
\text { frying oil } \\
\text { (UFO) }\end{array}$ & $\begin{array}{l}\text { Base } \\
(\mathrm{NaOH})\end{array}$ & 1.1 & Methanol & $1: 7.5$ & $\begin{array}{l}70 \mathrm{LC}, 30 \\
\min \end{array}$ & 85.3 \\
\hline & & $\begin{array}{l}\text { Base } \\
(\mathrm{KOH})\end{array}$ & 1.5 & & & & 86.0 \\
\hline & & $\begin{array}{l}\text { Base } \\
(\mathrm{CH} 3 \mathrm{ON} \\
\text { a) }\end{array}$ & 1.3 & & & & 89.0 \\
\hline \multirow[t]{2}{*}{$\begin{array}{l}\text { Narasimharao et } \\
\text { al. (2007) }\end{array}$} & $\begin{array}{l}\text { Soybean } \\
\text { oil }\end{array}$ & $\begin{array}{l}\text { Acid } \\
\left(\mathrm{H}_{2} \mathrm{SO}_{4}\right)\end{array}$ & 1 & Methanol & 01:30 & $65 \mathrm{LC}, 50 \mathrm{~h}$ & - \\
\hline & & & & Ethanol & & $78 \mathrm{LC}, 18 \mathrm{~h}$ & - \\
\hline
\end{tabular}




\begin{tabular}{|l|l|l|l|l|l|l|l|}
\hline & & & Butanol & & $117 \mathrm{LC}, 3 \mathrm{~h}$ & - \\
\hline Gof et al. (2004) & $\begin{array}{l}\text { Soybean } \\
\text { oil }\end{array}$ & $\begin{array}{l}\text { Acid } \\
\left(\mathrm{H}_{2} \mathrm{SO}_{4}\right)\end{array}$ & 0.5 & Methanol & $01: 09$ & $\begin{array}{l}100 \mathrm{LC}, 3.5 \\
\text { bar,8 h }\end{array}$ & - \\
\hline $\begin{array}{l}\text { Meher et al. } \\
(2006)\end{array}$ & $\begin{array}{l}\text { Karanja } \\
\text { oil }\end{array}$ & $\begin{array}{l}\text { Base } \\
(\mathrm{KOH})\end{array}$ & 1 & Methanol & $01: 06$ & $\begin{array}{l}65 \mathrm{LC}, 2 \\
\mathrm{~h}, 360 \mathrm{rpm}\end{array}$ & 98 \\
\hline
\end{tabular}

\subsubsection{Acid Catalysed Transesterification}

In this method, a glyceride is reacted with alcohol under the influence of acid catalysts to form biodiesel and glycerol (Likozar and Levec, 2014). Common acid catalysts utilised for biodiesel production are sulphuric acid and hydrochloric acid. This acid catalyst is not sensitive to feedstock purity such as a base catalyst. In performing this process, the biodiesel is mixed directly with the feedstock. This enables the reaction to progress in a single step unlike a two-step process which has two reactions. A study by Al-Widyan, M, I, et al., (2002) aimed at assessing the effect of HCL and $\mathrm{H}_{2} \mathrm{SO}_{4}$ yielded low kinematic viscous and high pure biodiesel. $\mathrm{H}_{2} \mathrm{SO}_{4}$, showed better catalysis compared to HCL. This process is slower and more expensive in comparison to the base catalysed method. Furthermore, this process is performed under intense temperature and pressure as well as higher alcohol to molar ratio making it unfavourable for commercial application (Lam et al., 2010). Acids are also corrosive in nature hence they can react with metals in production equipment to form unwarranted metal oxides. This requires that highly expensive stainless-steel production equipment used for biodiesel production. The mechanism is shown in Figure 6. Heterogenous solid catalysts have been identified as more suitable for WCO and high FFA containing feedstocks since catalyst can be easily recovered from the product mixture, this process produces pure biodiesel and catalyst usage lasts for longer periods compared to homogenous catalysts.

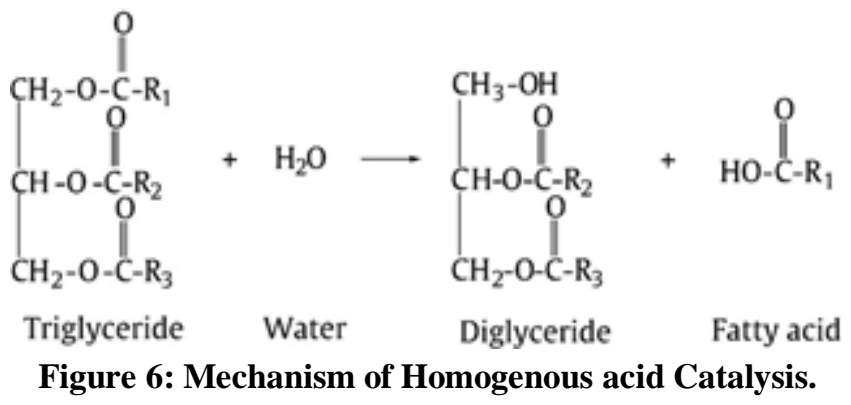

\subsubsection{Other Heterogenous Catalysts}

Fly ash, an inorganic by-product derived from the coal burning cycle comprises mainly $\mathrm{SiO}_{2}$ and $\mathrm{Al}_{2} \mathrm{O}_{3}$ components as impurities which are ecological toxins. Considering its significant conservation and ecological ramifications, the removal or use of fly ash will address these thereof. Thus, the advancement of naturally safe applications for the usage of coal fly ash is vital. Fly ash is currently mainly utilized as a building material and in other structural design work (concrete) however, much of it is still disposed of in lakes or landfills. Items produced using fly debris utilize refined fly ash which has been cleaned of impurities (López-Delgado et al., 2020). Fly ash can be utilized to make zeolite. Fly ash is an agglomerate of microspheres, which are primarily made from $\mathrm{Si}$ and $\mathrm{Al}$ with minor measures of $\mathrm{Fe}, \mathrm{Na}, \mathrm{K}, \mathrm{Ca}, \mathrm{P}, \mathrm{Ti}$, and $\mathrm{S}$. The significant mineral compound is formless aluminosilicate (glass) however other glasslike minerals are additionally present, for example, mullite, quartz, hematite, magnetite, lime, anhydrites, and feldspar (López-Delgado et al., 2020). This substance's mineralogical and textural properties make fly ash suitable as a source material for zeolite amalgamation. The transformation of fly ash into zeolite circumvents the disposal challenges and transforms waste material into a valuable 
one. A few investigations have effectively developed zeolites from fly ash under various reaction conditions. Development of various zeolite mineralogies and cations are dependent on the properties of the used fly ash. These conditions include temperature, pressure, and time (Sánchez Hernández, 2018)

Many metal oxides have been studied for their transesterification interaction with oils; zirconium oxide and zinc oxide have shown great reactant catalytic effectiveness and great dependability when used to catalyse esterification and transesterification at the same time. Nonetheless, they have not been by and large utilized in the modern creation processes, predominantly on account of the high cost and challenges arising. Calcium oxide has a high essential strength and less ecological effects because of its low immiscibility in methanol. When contrasted with $\mathrm{KOH}$ or $\mathrm{NaOH}$, calcium oxide was shown to be effective with the added benefit of simple catalyst recuperation and better environmental performance.

\subsubsection{Two-Step Transesterification}

Both acid and base catalysed processes have their pros and cons regarding WCO biodiesel production. Consequently, both can be utilised in WCO biodiesel production in a two stage transesrification process. In the first stage, the acid catalysed method is utilised to lower the FFA below $1 \mathrm{wt} \%$ after which the base catalysed method is performed for the second stage of the biodiesel formation process. Esterification is performed to lower the acid value of the feedstock oil. Typically, the esterification process is carried out using an acid catalyst such as hydrochloric, sulphuric, or sulfonic acid (Ali et al., 2013; Raqeeb \& Bhargavi, 2015). The acid value of oil is usually evaluated by titration of a combination of oil with ethanol and diethyl ether (1:1) against $\mathrm{KOH}$ utilizing phenolphthalein as indicator. Its value is determined by the equation Acid worth $=56.1 * \mathrm{CV} / \mathrm{m}$; while $\mathrm{V}$ is the volume of $\mathrm{KOH}(\mathrm{mL}) ; \mathrm{C}$ is the concentration of $\mathrm{KOH}(\mathrm{M})$ and $\mathrm{m}$ is the mass of used in the test (g) (Sunthitikawinsakul and Sangatith, 2012). This titration technique is governed by international standard ASTMD664 (Farooq, 2015). Based on acid value evaluated, the type of catalysts is chosen. For an FFA under 1\%, the feedstock can be transesterified with a homogenous base catalyst with no pre-treatment step (Patil et al., 2018). Lessening water by preheating in an oven can limit the FFA (Patil et al., 2018). The primary parameters influencing the esterification process are the alcohol to methanol proportion, catalyst and its concentration utilized, and the reaction temperature (Javidialesaadi \& Raeissi, 2013). A study by Leung et al. (2010) utilising the two-step process on the waste canola oil biodiesel production process revealed superior results compared to conventional acid and base processes. The researchers initially evaluated the optimal conditions that were suitable for the feedstock.

\subsubsection{Non-Catalysed Transesterification}

Supercritical methanol has been created to provide another method of delivering biodiesel. Under this supercritical condition, the transesterification process is rapid producing high yields of WCO biodiesel. Increasing temperatures have been noted to result in increased conversion efficiency of biodiesel (Demirbas, 2005). Besides, this technique has made cleansing of biodiesel a lot simpler as no catalysts are utilized in biodiesel production. In this process, soap formation is avoided as there is no water content available to enhance its formation (Barnwal \&Sharma, 2005). Be that as it may, the downsides of this supercritical transesterification method are a result of high pressures and temperatures which require advanced equipment. This is hampering its adoption as well because this will increase the capital cost of plant development. Other strategies that have been adopted to lower these critical working conditions include the addition of cosolvents such as $\mathrm{CO}_{2}$, calcium oxide and subcritical liquor (Vyas et al., 2010). Much exploration work has been completed for biodiesel creation from different feedstocks under various conditions utilizing supercritical liquor. Some conditions for non-catalysed processes are shown in Table 5. 
Table 5: Reports on Non-Catalysed Processes.

\begin{tabular}{|c|c|c|c|c|c|c|c|}
\hline Ref. & $\begin{array}{l}\text { Vegetable } \\
\text { Oil }\end{array}$ & $\begin{array}{l}\text { Molar } \\
\text { Ratio }\end{array}$ & Alcohol & $\begin{array}{l}\text { Temperature } \\
\text { and Pressure }\end{array}$ & $\begin{array}{c}\text { Reaction } \\
\text { Time }\end{array}$ & $\begin{array}{c}\text { Reactor } \\
\text { Type }\end{array}$ & $\begin{array}{c}\text { Conversion } \\
(\%)\end{array}$ \\
\hline $\begin{array}{l}\text { Dincer } \\
(2008)\end{array}$ & Rapeseed oil & $42: 01: 00$ & Methanol & $\begin{array}{l}350{ }^{\circ} \mathrm{C}, 45 \\
\mathrm{MPa}\end{array}$ & $240 \mathrm{~s}$ & $\begin{array}{l}5 \mathrm{ml} \\
\text { Inconel- } \\
625 \\
\text { reactor }\end{array}$ & 95 \\
\hline $\begin{array}{l}\text { Madras et } \\
\text { al. (2004) }\end{array}$ & $\begin{array}{l}\text { Sunflower } \\
\text { oil }\end{array}$ & 40:01:00 & Methanol & $\begin{array}{l}350{ }^{\circ} \mathrm{C}, 200 \\
\text { bar }\end{array}$ & $40 \mathrm{~min}$ & $\begin{array}{l}8 \mathrm{~mL} \mathrm{SS} \\
\text { reactor }\end{array}$ & 96 \\
\hline \multirow[t]{2}{*}{$\begin{array}{l}\text { Rathore } \\
\text { and } \\
\text { Madras } \\
(2007)\end{array}$} & Jatropha oil & 40:01:00 & Methanol & $\begin{array}{l}350^{\circ} \mathrm{C}, 200 \\
\text { bar }\end{array}$ & $40 \mathrm{~min}$ & $\begin{array}{l}11 \mathrm{~mL} \\
\text { reactor of } \\
\mathrm{SS} 316\end{array}$ & $>90$ \\
\hline & Soyabean oil & 40:01:00 & Methanol & $\begin{array}{l}310^{\circ} \mathrm{C}, 35 \\
\mathrm{MPa}\end{array}$ & $25 \mathrm{~min}$ & $\begin{array}{l}75 \mathrm{ml} \text { tube } \\
\text { reactor }\end{array}$ & - \\
\hline $\begin{array}{l}\text { Bunyakiat } \\
\text { et al. } \\
(2006) \\
\text { Bunyakiat } \\
\text { et al. } \\
(2006) \\
\end{array}$ & $\begin{array}{l}\text { Coconut, } \\
\text { palm oils }\end{array}$ & 42:01:00 & Methanol & $\begin{array}{l}350{ }^{\circ} \mathrm{C}, 19.0 \\
\mathrm{MPa}\end{array}$ & $400 \mathrm{~s}$ & $\begin{array}{l}\text { Tubular } \\
\text { flow } \\
\text { reactor }\end{array}$ & $95-96$ \\
\hline $\begin{array}{l}\text { Demirbas } \\
(2009)\end{array}$ & $\begin{array}{l}\text { Hazelnut } \\
\text { kernel oil }\end{array}$ & 41:01:00 & Methanol & $350^{\circ} \mathrm{C}, \mathrm{NA}$ & $300 \mathrm{~s}$ & $\begin{array}{l}100 \mathrm{ml} \\
\text { stainless } \\
\text { steel } \\
\text { reactor }\end{array}$ & 95 \\
\hline
\end{tabular}

A study by Hawash et al. (2009) uncovered that a $100 \%$ yield of biodiesel can be produced in 240 seconds by utilizing supercritical methanol at a temperature of $320{ }^{\circ} \mathrm{C}$ and under a pressure of $8.4 \mathrm{MPa}$. In addition, safety issues are a major issue of concern due to high pressure and temperature conditions required for this method. The process progression is depicted in figure 7.

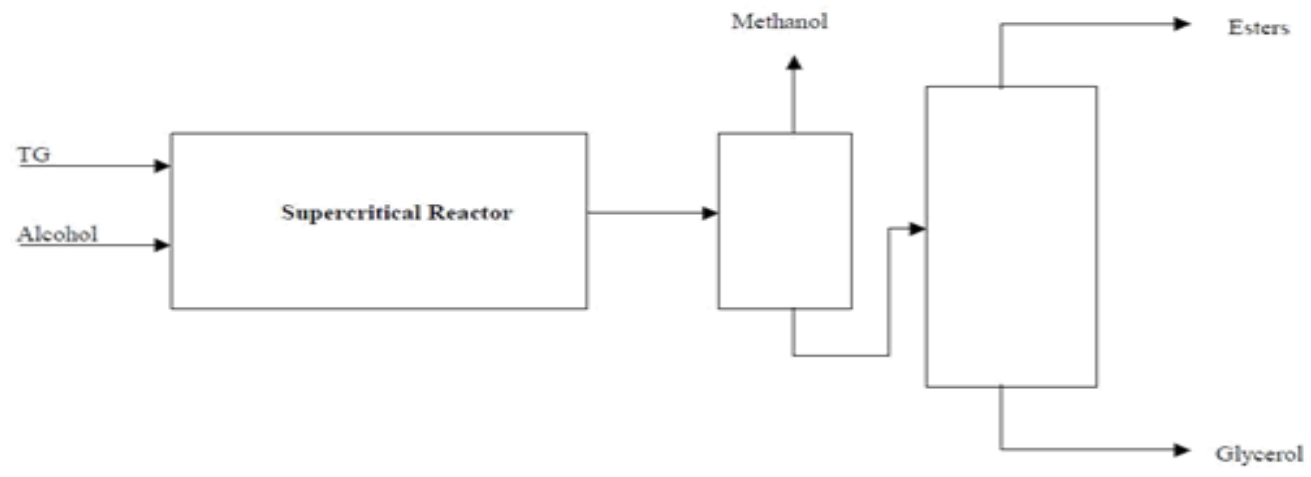

Figure 7: Supercritical Transesterification Process.

\subsubsection{Enzyme Catalysis}

The quest for ecosystem-harmless approaches for biodiesel creation has intensified investigation into the utilization of enzymes as process catalysts. The drawbacks of conventional acid and base such as feedstock pre-treatment, catalyst expulsion, high energy usage and generation of wastewater which require post treatment, are reduced in enzyme catalysed processes. Enzyme catalysts perform as biocatalysts using lipases derived from microorganisms, animals, and plants. These 
lipases are categorised as extracellular lipases and intracellular lipases. Intracellular lipases are normally utilized in the entire cell structure, thereby eliminating chemical purification and selection process hurdles. To improve its stability and reus-capacity, lipases can be immobilized on a few materials. Biocatalysts are described as having high selectivity and as an effective method, resulting in a high biodiesel yield without side reaction occurrence. Furthermore, in this method glycerol recovery is simpler and of higher grade when contrasted with those from base catalysed processes. In addition to that, enzyme catalysed processes are compatible with a wide scope of fatty oil sources, and are applicable with FFA lying within the range of $0.5 \%$ to $90 \%$. A study performed with Rhizopusoryzae lipase demonstrated that free unsaturated fats (FFA) contained in WCO oils and fats can be efficiently converted to biodiesel at lower temperatures ranging from $30{ }^{\circ} \mathrm{C}$ to $40{ }^{\circ} \mathrm{C}$ (Sattari et al., 2015). This gives enzyme catalysis an edge over base catalysts which produce lower yields at higher temperatures when the feedstock oil is of high FFA content. While ethanol and methanol are ordinarily used as alcohol in most transesterification process, these are shown to have significant inhibitory consequences for biocatalysts. An examination by López-Fernández et al. (2021) found that chemical deactivation expanded with expanding carbon chain of the liquor. Notwithstanding, this inhibitory impact can be resolved by utilizing a stepwise addition of the liquor.. An examination by Shimada et al. (2002) showed that the ideal methanol:oil proportion in dissolvable free biocatalytic framework was 1.5. The utilization of natural solvents, for example, $n$-hexane, $n$-heptane, petroleum ether and cyclohexane is another factor that influences the efficiency of bio. Despite the allure of biocatalysis, its business applications are hampered by specific drawbacks. These are: 1) high creation cost of the lipase catalyst, 2) higher response times when contrasted with base-catalysed response systems; and 3) recovery and re-utilization of biocatalysts restricted with a long working time. Reaction times of up to $90 \mathrm{~h}$ are possible utilizing different reactor types. Also, there is an interaction between the operational conditions and the reactant properties of the catalysts.

\subsection{Alcohol to Oil Molar Ratio}

The molar ratio of alcohol to oil is influential to transesrification process progression. This is because the molar ratio influences the reverse reaction process. Different alcohols like methanol, ethanol, tert-butanol, butanol, and isopropanol can be applied for transesterification of oils (Shuit et al., 2012). Lower alcohols are preferred since they are acquired at a low cost compared to higher alcohol options. Methanol is invaluable over other lower alcohols, fundamentally because of its chemical and physical qualities. Methanol reacts with feedstock oil at a faster rate speeding up the rate of reaction. This alcohol dissolves quickly in most alkali catalysts such as $\mathrm{KOH}$ and $\mathrm{NaOH}$. However, the alcohol must contain optimal water content since an excessive amount will react and cause saponification of the oil. From the stochiometric equation, it can be noted that a ratio of 3:1 is the most appropriate alcohol to oil ratio for the process. Higher ratios have been adopted since they favour higher yield formation in shorter reaction duration. This has necessitated utilisation of higher molar to oil ratio of 6:1 and higher (Wu et al., 2016). The biodiesel production process produces glycerol as a by-product which can be separated from the fuel with ease as it isolated from slurry by settling or hand centrifugation since it is basically insoluble in biodiesel (Chuah et al., 2016). Be that as it may, when utilizing high liquor to-oil molar proportions, glycerol dissolvability in biodiesel increases and free glycerol may remain suspended. This can be caused by alcohols becoming a reaction agent promoting dissolving of glycerol in biodiesel fuel. This will result in higher process costs as separation of glycerol becomes more difficult. This calls for proper selection of optimal alcohol to oil molar ratio for a favourable economic biodiesel production process. Wu et al. (2016) performed a study on soyabean biodiesel production using $\mathrm{NaOH}$ catalysed transesterification process (from 4.5:1 to 9:1) which revealed that the optimal molar to oil ratio was 7:1. The optimal molar ratio yielded $98 \%$ within an hour of reaction. This also justified that utilisation of higher molar ratio above 
6:1 was possible and could bring better outcomes. A study by Sanli et al. (2019) evaluated the optimal molar ratio from 3:1 to 20:1 and several alkali-based catalysts gave similar outcomes. The researchers concluded that the appropriate molar ratio of $8: 1$ with sodium methoxides of $1.40 \mathrm{wt} . \%$ for 120 minutes yielded the best results. Under those conditions, a conversion efficiency of $99 \%$ was unveiled.

\subsection{Biodiesel Production Modes}

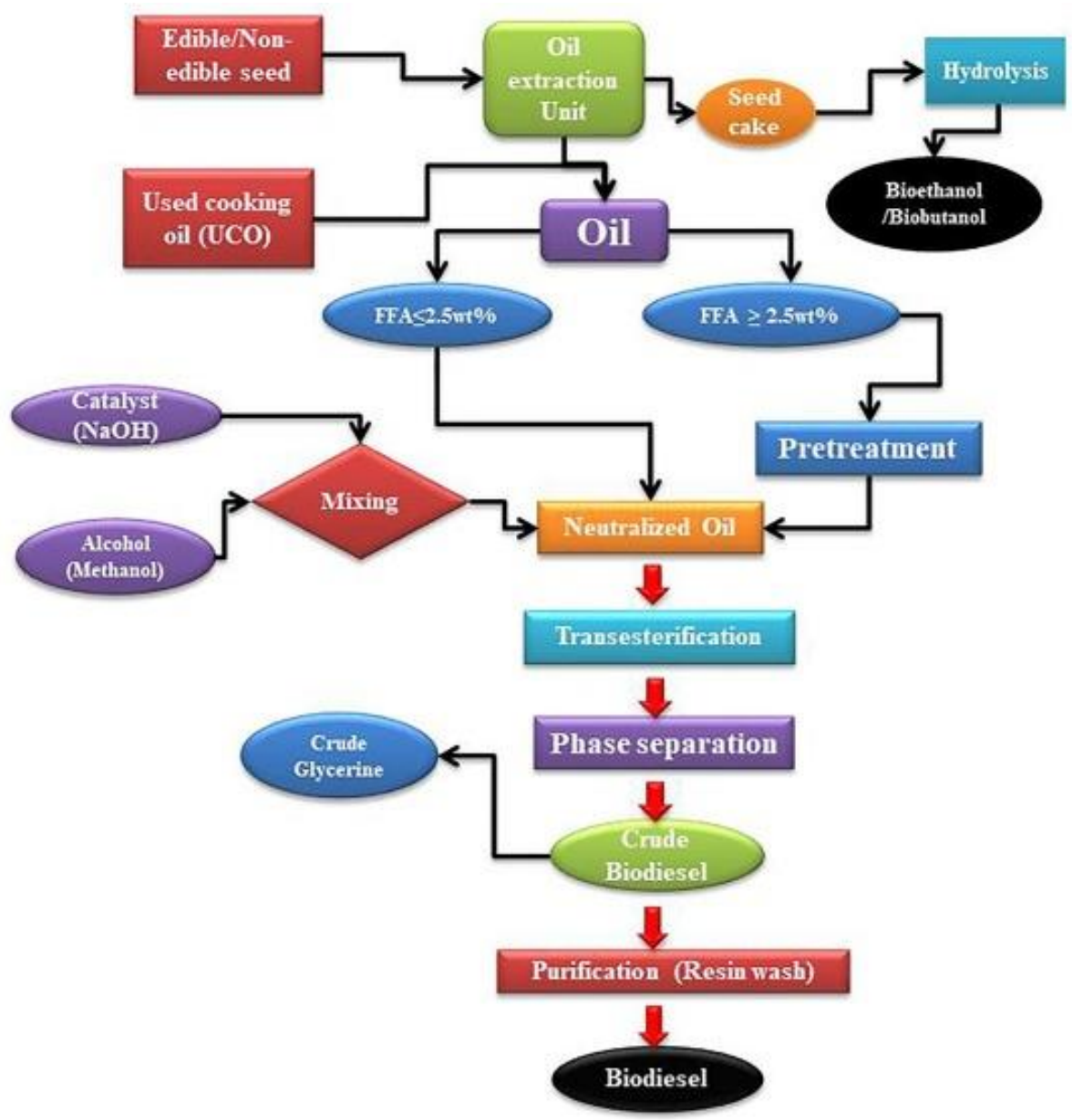

Figure 8: Waste Biodiesel Production Process.

Batch, semi batch, or continuous modes are the most utilised production modes for biodiesel production. The most normally utilized strategy for industrial biodiesel is the batch process. In a batch process, there is no inflow and outflow of materials during the process, and a limited number of reactants is orchestrated into the reactor a given time. When the process is complete, the whole slurry is shipped off to a purification process. Semi-batch process mode is a variation of batch process mode having higher selectivity and better control on reaction temperature. In semi batch process mode, as the reaction continues, one reagent or item is added at intervals whilst the reactants will be eliminated also at scheduled intervals from the reactor. Like the batch mode process, the production rate in the semi-batch process is restricted, and the biodiesel creation cost is moderately high. In the continuous process mode reagents are added continually and the products are continuously removed from the reactor. The batch process is the predominantly utilised process mode for biodiesel creation plants worldwide since it is suitable for small to medium scale biodiesel plants. 


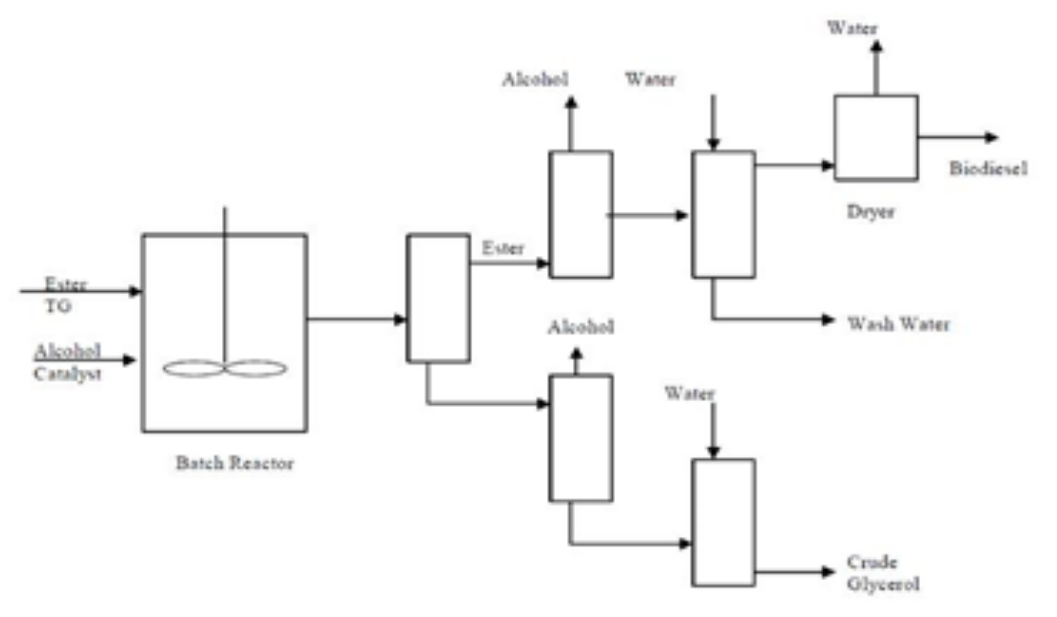

Figure 9: Batch Process Flow Diagram. Batch Process Mode.

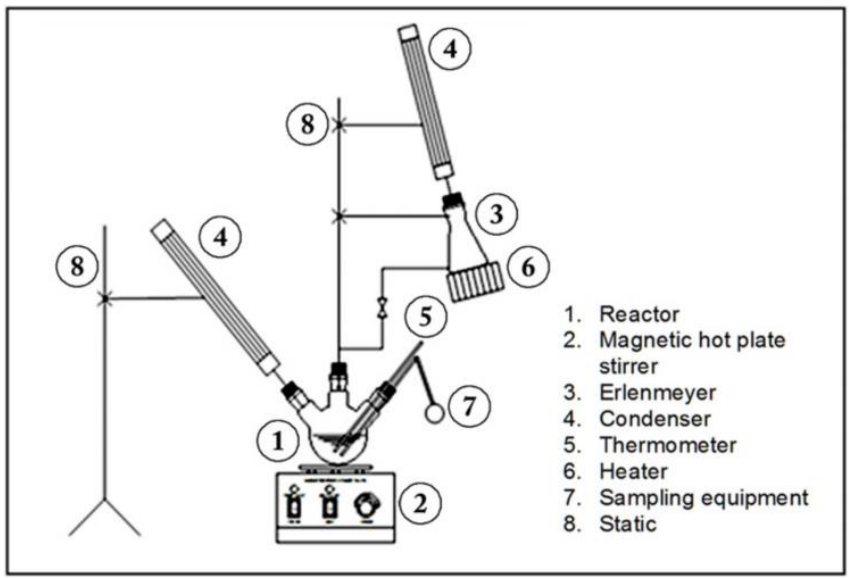

Figure 10: Batch Reactor (Patil et al., 2018).

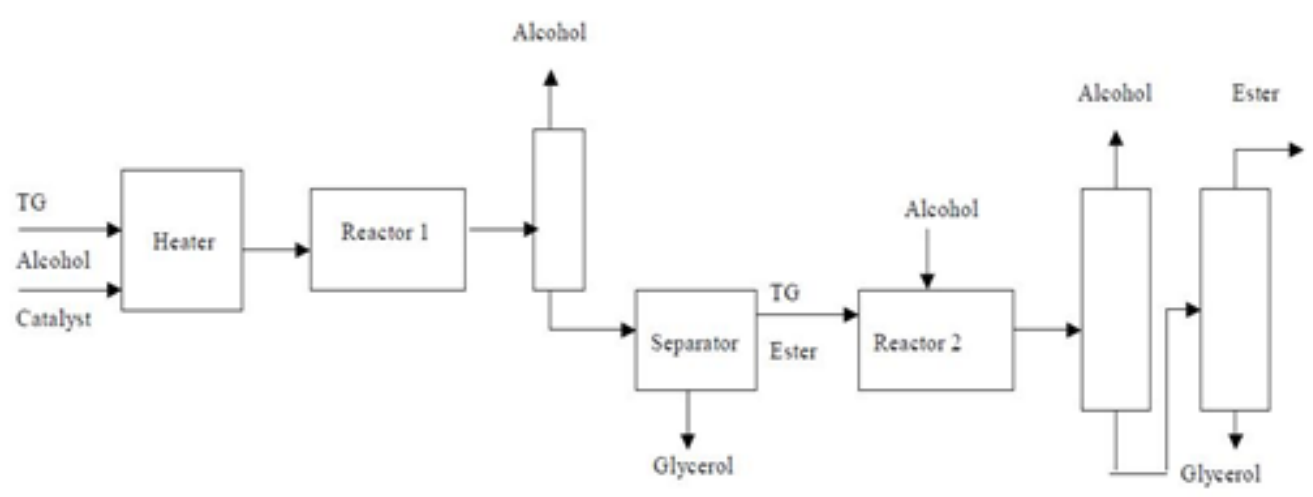

Figure 11: Continuous Process Flow Diagram. 


\subsection{Ultrasound Assisted Transesterification Method}

The ultrasonic method has been perceived as being a useful technique to improve the mass exchange rate between immiscible fluids and a heterogeneous reaction media (Aghbashlo et al., 2019). Consequently, it has been utilized to increase the reaction rates for various chemical reactions. Ultrasound is that sound whose frequency cannot be detected by human ear. The ordinary sound frequency that can be identified by humans lies somewhere in the range of $16 \mathrm{kHz}$ and 18 $\mathrm{kHz}$, however the frequency of ultrasound for the most part lies between $20 \mathrm{kHz}$ and $100 \mathrm{MHz}$. This high frequency sound wave has the capability to cause expansions and compressions of the molecules within the medium it penetrates. This enhances the creation of fine bubbles due to this phenomenon (Pukale et al,. 2015). These bubbles contain energy capable of influencing chemical and mechanical changes. In line with that, the bubbles penetrate the phase boundaries and resulting in formation of an emulsified liquid phase. This method has been demonstrated to be an effective blending tool which gives adequate activation energy which can be utilised to increase biodiesel production (Singh et al., 2007). Furthermore, this technique will result in lowering the molar ratio and a significant reduction in energy utilisation (Vyas et al., 2010). A few studies have utilised ultrasound aided transesterification of WCO and yielded favourable outcomes (Delavari et al., 2015; Jian-Xun et al., 2007; Gharat \& Rathod, 2013).

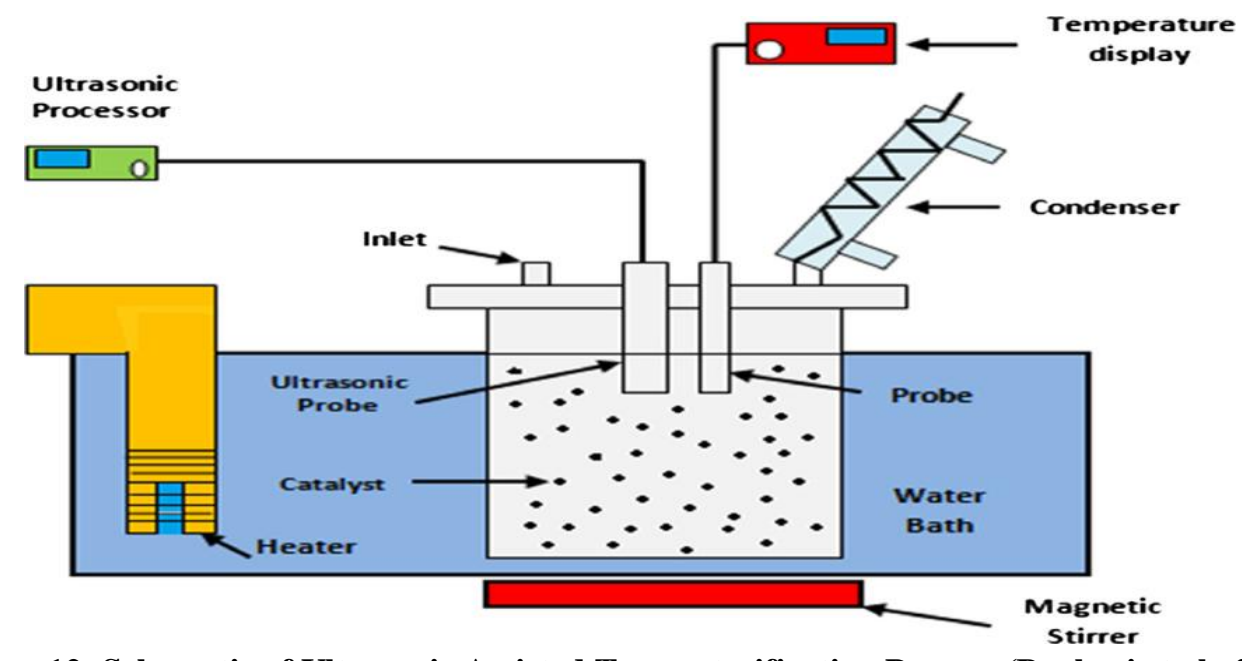

Figure 12: Schematic of Ultrasonic Assisted Transesterification Process (Buchori et al., 2016).

\subsection{Biodiesel Purification Process}

Biodiesel should be purified before usage to reduce the possibilities of its contaminants blocking fuel supply line components such as injectors, pumps, and filters. Residue from WCO, for the most solid contaminants, can be eliminated by centrifugation as well as filtration before the biodiesel creation process. These contaminants need to be removed in order to maintain biodiesel quality. Generally, they are two methods used to purify and filter biodiesel fuel. The more customary wet washing technique is generally used to eliminate excess contaminants and reagents used for biodiesel production. In this method, a fine mist of water is showered over the fuel. The fuel's contaminations are removed as the water settles to the lower part of the tank. Nonetheless, the incorporation of extra water into the process offers numerous drawbacks, including increased production cost and prolonged duration. This has brought about utilization of the dry purification method. In the dry wash method, the duration of biodiesel production is reduced significantly, as is the cost of production as the water required is minimal in comparison to the wet wash method. In addition, the dry wash method requires less space and the product production is of higher quality. The resin used for purification can also be reused. 
The principal benefits of utilizing the dry washing method are the significant reduction in effluent formation (making the process harmless to the environment), and the considerable decrease in the time taken to perform the purification process. The wet washing method is time consuming as it entails performing two washing process followed by centrifugation, all of which can be substituted by the one stage dry wash method. Faccini et al. (2011) examined the expulsion of glycerol from biodiesel from WCOs containing a high FFA content by utilizing silica and accomplished high biodiesel yields. Another promising dry washing resin is Amberlite BD10 DRY ${ }^{\circledR}$ which has since been adopted for WCO biodiesel purification. Purolite PD $206^{\circledR}$ is also very useful for purifying biodiesel containing higher water content, soaps, and glycerol, resulting in higher biodiesel yields and quality. A study performed by Berrios and Skelton (2008) affirmed that usage of Purolite PD 20 results in better yields and high-quality biodiesel when compared to wet purification methods.

\subsection{Prospects of Waste Cooking Oil Biodiesel Production}

Energy is a fundamental factor in promoting economic development and is key in alleviating poverty. Biodiesel, a renewable biofuel, has been portrayed in this survey as a fuel with the potential to supplant fossil diesel in the future. Biodiesel and its blends have gone through several corroborative tests and revealed better emission attributes hence they will play an important role as a fuel of the future. The availability of plenty of feedstock coupled with the introduction of advanced biodiesel processing technologies has cemented biodiesel as a viable alternative fuel to fossil diesel fuel. The utilization of WCO furthermore has aided in resolving the food versus fuel debate. The worldwide WCO market is expected to extend at a faster rate in the upcoming future. The increase of the worldwide market can partly be caused by the expanding interest in biodiesel by both developed and developing countries. Most developing economies are switching to biofuels due to increases in air contamination, therefore is speeding up the development of the worldwide WCO market.

Table 6: Average Costs of Feedstock for Biodiesel Production.

\begin{tabular}{|l|c|}
\hline \multicolumn{1}{|c|}{ Oil } & Price (Us dollar /ton) \\
\hline WCO & 225 \\
\hline Rape seed & 825 \\
\hline Soyabean & 770 \\
\hline Palm Oil & 705 \\
\hline
\end{tabular}

It can be noted from Table 6, that WCO feedstock oil can be acquired at a lower cost compared to virgin vegetable oil. WCO cost is two to three times lower than vegetable oil, and this results in lower feedstock costs. The cost of biodiesel from WCO is reported in the range of \$0.36/1 to \$0.42/1 (Sanjib, Kumar, Karmee et al., 2015). The utilization of WCO is high in animal feed production but this has been discouraged especially in Europe because of the side-effects which have been identified with its usage (T, D.Tsoutsosa et al ., 2016). Despite its numerous benefits as a sustainable renewable fuel, biodiesel presents various technical challenges that must be rectified before it will be more attractive as an alternative to fossil diesel. These issues include improving its cold flow properties, and oxidation stability related issues. Storage related issues are becoming a barrier to biodiesel deployment, but these can be circumvented by the use of fuel additives. This requires proper tank treatment before filling them with biodiesel to eliminate moisture and other substances which can promote oxidation of fuel. In addition to that, regular checks ought to be performed for indications of degradation. The utilization of fuel additives and other fuel property enhancements can remain a vital strategy in the foreseeable future to enhance biodiesel competitiveness unless upgraded compositional alterations are invented. Likewise, additives utilized for blends of a given feed stock might be incompatible with the types of feed stock available in different regions which underlines the requirement for further research on fuel additives that are suitable for localized feed stocks. 
The essential market for biodiesel in the future is probably going to be a blended mixture with fossil diesel. Thus, it is important to study how biodiesel prepared from different feed stocks impacts significant fuel properties of the resultant fossil diesel/biodiesel blends. Biodiesel in the coming years may face competition from non-ester sustainable diesel fuels like those delivered from hydro-processing of vegetable oils or animal fats. Nonetheless, the numerous ecological advantages and utilizations of biodiesel will continue to ensure that a considerable market exists for this option compared to traditional fossil diesel fuel. However, to yield substantial benefits large scale bio-processing plants for future biodiesel creation must be set up now.

\section{CONCLUSIONS}

Considering the reviews and analysis introduced in this paper, it is of paramount importance to note that biodiesel production requires continuous process development that will enable it to reinforce its possibilities of becoming a viable alternative fuel for diesel engines. The above analyses provide a concise summary of the various catalysts and pathways that can be utilized for WCO biodiesel production. WCO is a viable feedstock for biodiesel production considering its accessibility and the minimal cost of acquisition. However, this feedstock oil has contaminants which impact negatively on biodiesel production. These compounds are a result of the frying process through which the oil passes. These undesirable substances are polymers, FFA compounds and high-water content. To eliminate these substances, pre-treatment of the WCO has to be performed. If the FFA and water substance are $<1 \mathrm{wt} \%$ and $<0.5 \mathrm{wt} \%$, respectively, base catalysed process will be the ideal method of biodiesel production. Higher FFA substances in oil (>1 wt \%) require acid catalysed transesterification in order to suppress soap formation. However, considering the necessity of high catalyst concentration and high molar proportion, the acid catalysed process is not encouraged for WCO biodiesel production. This then calls for a two-step method, although it may require more steps which, if not properly managed, can increase the production cost. Supercritical catalysed transesterification is emerging as the most promising alternative to all conventional catalysed processes, however, the requirements such as high temperature $\left(300{ }^{\circ} \mathrm{C}\right)$, high pressures $(40 \mathrm{MPa})$, and high molar proportion of oil to liquor (1:42) makes the utilization of this process unfavourable for commercial production. In this exploration study, the principal objective is the quest for proficient cycles of delivering WCO biodiesel that will reinforce its possibility as the cutting-edge green fuel through the different methods. The initially optimized twostep process conditions will be examined and thereafter methanolsis of calcium oxide coupled to pre-treatment will be utilized for process design and evaluation of batch process ultrasound and constant stream circle measure advancements by the utilization of homogeneous base impetuses. In addition, this investigation will utilize nano particles to circumvent the fuel property shortfalls which could have been identified in WCO feedstocks. In addition, further investigation will be undertaken to develop a viable catalyst that can be utilized for both virgin and used oils. The trial examinations performed on WCO to fulfil the research objectives will be documented in subsequent papers.

\section{REFERENCES}

1. Al-Widyan, M, I., Al-Shyoukh, A, O., Experimental evaluation of the transesterification of waste palm oil into biodisesl. Bioresource Technology 2002; 85: 253-6.

2. Agarwal, A. K. (2007). Biofuels (alcohols and biodiesel) applications as fuels for internal combustion engines. Progress in Energy and Combustion Science 33(3), 233-271.

3. Aghbashlo, M., Hosseinpour, S., Tabatabaei, M., \& Soufiyan, M. M. (2019). Multi-objective exergetic and technical optimization of a piezoelectric ultrasonic reactor applied to synthesize biodiesel from waste cooking oil (WCO) using soft 
computing techniques. Fuel, 235, 100-112.

4. Ali, M. H., Mashud, M., Rubel, M. R., \& Ahmad, R. H. (2013). Biodiesel from Neem oil as an alternative fuel for Diesel engine. Procedia Engineering, 56, 625-630.

5. Alptekin, E., Canakci, M., \& Sanli, H. (2011). Methyl ester production from chicken fat with high FFA. World Renewable Energy Congress-Sweden; 8-13 May; 2011; Linköping; Sweden, Linköping University Electronic Press.

6. Azócar, L., Heipieper, H. J., \& Navia R. (2010). Biotechnological processes for biodiesel production using alternative oils. Applied Microbiology and Biotechnology, 88(3), 621-636.

7. Barnwal, B. \& Sharma, M. (2005). Prospects of biodiesel production from vegetable oils in India. Renewable and Sustainable Energy Reviews, 9(4), 363-378.

8. Berrios, M. \& Skelton, R. (2008). Comparison of purification methods for biodiesel. Chemical Engineering Journal, 144(3), $459-465$.

9. Brent, A. C., Wise, R., \& Fortuin, H. (2009). The viability of the South African biofuels industrial strategy. International Journal of Environment and Pollution, 39(1-2), 74-91.

10. Buchori, L., Istadi, I., \& Purwanto, P. (2016). Advanced chemical reactor technologies for biodiesel production from vegetable oils-a review. Bulletin of Chemical Reaction Engineering \& Catalysis, 11(3), 406-430.

11. Bunyakiat, K., Makmee, S., Sawangkeaw, R., \& Ngamprasertsith, S. (2006). Continuous production of biodiesel via transesterification from vegetable oils in supercritical methanol. Energy \& Fuels, 20(2), 812-817.

12. Che, F., Sarantopoulos, I., Tsoutsos, T., \& Gekas, V. (2012). Exploring a promising feedstock for biodiesel production in Mediterranean countries: a study on free fatty acid esterification of olive pomace oil. Biomass and Bioenergy, 36, 427-431.

13. Chen, H., Xie, B., Ma, J., \& Chen, Y. (2018). NOx emission of biodiesel compared to diesel: Higher or lower? Applied Thermal Engineering, 137, 584-593.

14. Chuah, L., Aziz, A., Yusup, S., Klemes, J., \& Bokhari, A. (2016). Waste cooking oil biodiesel via hydrodynamic cavitation on a diesel engine performance and greenhouse gas footprint reduction. Chemical Engineering Transactions, 50, 301-306.

15. Costa, E., Almeida, M. F., da Conceição Alvim-Ferraz, M. \& Dias, J. M. (2018). Effect of Crambe abyssinica oil degumming in phosphorus concentration of refined oil and derived biodiesel. Renewable Energy, 124, 27-33.

16. Cvengroš, J., \& Cvengrošová, Z. (2004). Used frying oils and fats and their utilization in the production of methyl esters of higher fatty acids. Biomass and Bioenergy, 27(2), 173-181.

17. de Jong, S., Hoefnagels, R., Wetterlund, E., Pettersson, K., Faaij, A., \& Junginger, M. (2017). Cost optimization of biofuel production-The impact of scale, integration, transport and supply chain configurations. Applied Energy, 195, 1055-1070.

18. Delavari, A., Halek, F. \& Amini, M. (2015). Continuous biodiesel production in a helicoidal reactor using ultrasound-assisted transesterification reaction of waste cooking oil. Clean Technologies and Environmental Policy, 17(1), 273-279.

19. Demirbas, A. (2005). Biodiesel production from vegetable oils via catalytic and non-catalytic supercritical methanol transesterification methods. Progress in Energy and Combustion Science, 31(5-6), 466-487.

20. Demirbas, A. (2009). Characterization of biodiesel fuels. Energy Sources, Part A, 31(11), 889-896.

21. Dias, J. M., Alvim-Ferraz, M. C. \& Almeida, M. F. (2008). Comparison of the performance of different homogeneous alkali catalysts during transesterification of waste and virgin oils and evaluation of biodiesel quality. Fuel, 87(17-18), 3572-3578.

22. Dincer, K. (2008). Lower emissions from biodiesel combustion. Energy Sources, Part A, 30(10), 963-968. 
23. Faccini, C. S., de Cunha, M. E., Moraes, M. S. A., Krause, L. C., Manique, M. C., Rodrigues, M. R. A., Benvenutti E. V., \& Caramão, E. B. (2011). Dry washing in biodiesel purification: a comparative study of adsorbents. Journal of the Brazilian Chemical Society, 22(3), 558-563.

24. Farooq, M., Ramli, A., \& Naeem, A. (2015). Biodiesel production from low FFA waste cooking oil using heterogeneous catalyst derived from chicken bones. Renewable Energy, 76, 362-368.

25. Ferrari, R. A., Leticia, A. \& Pighinelli, T. (2011). Biodiesel production and quality, biofuel's engineering process technology. London: InTech.

26. Franco, S., Mandla, V. R. \& Rao, K. R. M. (2017). Urbanization, energy consumption and emissions in the Indian context A review. Renewable and Sustainable Energy Reviews, 71, 898-907.

27. Gharat, N., \& Rathod, V. K. (2013). Ultrasound assisted enzyme catalyzed transesterification of waste cooking oil with dimethyl carbonate. Ultrasonics Sonochemistry, 20(3), 900-905.

28. Goff, M. J., Bauer, N. S., Lopes, S., Sutterlin, W. R., \& Suppes, G. J. (2004). Acid-catalyzed alcoholysis of soybean oil. Journal of the American Oil Chemists' Society, 81(4), 415-420.

29. Gog, A., Roman, M., Toşa, M., Paizs, C. \& Irimie, F. D. (2012). Biodiesel production using enzymatic transesterificationcurrent state and perspectives. Renewable Energy, 39(1), 10-16.

30. Günay, M. E., Türker, L. \& Tapan, N. A. (2019). Significant parameters and technological advancements in biodiesel production systems. Fuel, 250, 27-41.

31. Hajjari, M., Tabatabaei, M., Aghbashlo, M. \& Ghanavati, H. (2017). A review on the prospects of sustainable biodiesel production: A global scenario with an emphasis on waste-oil biodiesel utilization. Renewable and Sustainable Energy Reviews, 72, 445-464.

32. Hall, K. D., Guo, J., Dore, M. \& Chow, C. C. (2009). The progressive increase of food waste in America and its environmental impact. PloS One, 4(11), e7940.

33. Hamze, H., Akia, M. \& Yazdani, F. (2015). Optimization of biodiesel production from the waste cooking oil using response surface methodology. Process Safety and Environmental Protection 94, 1-10.

34. Hawash, S., Kamal, N., Zaher, F., Kenawi, O. \& El Diwani, G. (2009). Biodiesel fuel from Jatropha oil via non-catalytic supercritical methanol transesterification. Fuel, 88(3), 579-582.

35. Iso, M., Chen, B., Eguchi, M., Kudo, T. \& Shrestha, S. (2001). Production of biodiesel fuel from triglycerides and alcohol using immobilized lipase. Journal of Molecular Catalysis B: Enzymatic, 16(1), 53-58.

36. Javidialesaadi, A. \& Raeissi, S. (2013). Biodiesel production from high free fatty acid-content oils: Experimental investigation of the pretreatment step. APCBEE Procedia, 5, 474-478.

37. Jian-Xun, W., Huang, Q.-D., Huang, F.-H. \& Huang, Q.-J. (2007). Lipase-catalyzed production of biodiesel from high acid value waste oil using ultrasonic assistant. Chinese Journal of Biotechnology, 23(6), 1121-1128.

38. Karmee, S. K. \& Chadha, A. (2005). Preparation of biodiesel from crude oil of Pongamia pinnata. Bioresource Technology, 96(13), 1425-1429.

39. Kitani, O. (1999). Energy and biomass engineering, CIGR handbook of agricultural engineering. ASAE, St. Joseph, MI.

40. Lam, M. K., Lee, K. T. \& Mohamed, A. R. (2010). Homogeneous, heterogeneous and enzymatic catalysis for transesterification of high free fatty acid oil (waste cooking oil) to biodiesel: A review. Biotechnology Advances, 28(4), 500-518. 
41. Lee, K.-T., Foglia T. A., \& Chang, K.-S. (2002). Production of alkyl ester as biodiesel from fractionated lard and restaurant grease. Journal of the American Oil Chemists' Society, 79(2), 191-195.

42. Lertsathapornsuk, V., Ruangying, P., Pairintra, R., \& Krisnangkura, K. (2005). Continuous transethylation of vegetable oils by microwave irradiation. Proceedings of the 1st conference on energy network.

43. Leung, D. \& Guo, Y. (2006). Transesterification of neat and used frying oil: Optimization for biodiesel production. Fuel Processing Technology, 87(10), 883-890.

44. Leung, D. Y., Wu, X. \& Leung, M. (2010). A review on biodiesel production using catalyzed transesterification. Applied Energy, 87(4), 1083-1095.

45. Li, Z.-H., Lin, P.-H., Wu, J. C., Huang, Y.-T., Lin, K.-S. \& Wu K. C.-W. (2013). A stirring packed-bed reactor to enhance the esterification-transesterification in biodiesel production by lowering mass-transfer resistance. Chemical Engineering Journal, $234,9-15$.

46. Likozar, B. \& Levec, J. (2014). Transesterification of canola, palm, peanut, soybean and sunflower oil with methanol, ethanol, isopropanol, butanol and tert-butanol to biodiesel: Modelling of chemical equilibrium, reaction kinetics and mass transfer based on fatty acid composition. Applied Energy, 123, 108-120.

47. López-Delgado, A., Robla, J. I., Padilla, I., Lopez-Andres, S. \& Romero, M. (2020). Zero-waste process for the transformation of a hazardous aluminum waste into a raw material to obtain zeolites. Journal of Cleaner Production, 255, 120178.

48. López-Fernández, J., Benaiges, M. D. \& Valero, F. (2021). Second-and third-generation biodiesel production with immobilised recombinant Rhizopus oryzae lipase: Influence of the support, substrate acidity and bioprocess scale-up. Bioresource Technology, 334, 125233.

49. Madras, G., Kolluru, C. \& Kumar, R. (2004). Synthesis of biodiesel in supercritical fluids. Fuel, 83(14-15), 2029-2033.

50. Marchetti, J., Miguel, V. \& Errazu, A. (2007). Possible methods for biodiesel production. Renewable and Sustainable Energy Reviews, 11(6), 1300-1311.

51. Meher, L., Dharmagadda, V. S. \& Naik, S. (2006). Optimization of alkali-catalyzed transesterification of Pongamia pinnata oil for production of biodiesel. Bioresource Technology, 97(12), 1392-1397.

52. Mittelbach, M. \& Remschmidt, C. (2005). Biodiesel the comprehensive handbook second edit. Boersedruck Ges. mbH, Vienna.

53. Mofijur, M., Masjuki, H. H., Kalam, M., Atabani, A. E., Fattah, I. R. \& Mobarak, H. (2014). Comparative evaluation of performance and emission characteristics of Moringa oleifera and Palm oil based biodiesel in a diesel engine. Industrial Crops and Products, 53, 78-84.

54. Narasimharao, K., Lee, A. \& Wilson, K. (2007). Catalysts in production of biodiesel: a review. Journal of Biobased Materials and Bioenergy, 1(1), 19-30.

55. Sahara, Sana., Sadafb. Javed., Iqbala. Inam., Ullah. Haq., Nawaz. Bhattia., Shazi, Nourene., Habib-ur-Rehman., Jan, Nisarg., Munawar. Iqbalh (2018). Biodiesel production from waste cooking oil: An efficient technique to convert waste into biodiesel. Sustainable Cities and Society, 41, 220 -226

56. Patil, R., Gaikwad, S., Paratkar, H. \& Dhapodkar, K. (2018). Production of biodiesel from waste materials. Journal of Environmental Engineering and its Scope, 1(2), 9-14.

57. Pinzi, S., Leiva, D., López-García, I., Redel-Macías, M. D. \& Dorado, M. P. (2014). Latest trends in feedstocks for biodiesel production. Biofuels, Bioproducts and Biorefining, 8(1), 126-143. 
58. Pukale, D. D., Maddikeri, G. L., Gogate, P. R., Pandit, A. B. \& Pratap, A. P. (2015). Ultrasound assisted transesterification of waste cooking oil using heterogeneous solid catalyst. Ultrasonics Sonochemistry, 22, 278-286.

59. Raqeeb, M. A. \& Bhargavi, R. (2015). Biodiesel production from waste cooking oil. Journal of Chemical and Pharmaceutical Research, 7(12), 670-681.

60. Rashid, U., Anwar, F., Moser, B. R., \& Ashraf, S. (2008). Production of sunflower oil methyl esters by optimized alkalicatalyzed methanolysis. Biomass and Bioenergy, 32(12), 1202-1205.

61. Rathore, V. \& Madras, G. (2007). Synthesis of biodiesel from edible and non-edible oils in supercritical alcohols and enzymatic synthesis in supercritical carbon dioxide. Fuel, 86(17-18), 2650-2659.

62. Refaat, A., Attia, N., Sibak, H. A., El Sheltawy, S., \& ElDiwani, G. (2008). Production optimization and quality assessment of biodiesel from waste vegetable oil. International Journal of Environmental Science \& Technology, 5(1), 75-82.

63. R, Mohsin., Z, A, Majid., A.H. Shihnan., N. S. Nasri., Z. Sharer Effect of biodiesel blends on engine performance and exhaust emission for diesel dual fuel engine, Energy Conversion and Management, 88, 821 -828

64. Roy, M. M., Wang, W., \& Alawi, M. (2014). Performance and emissions of a diesel engine fueled by biodiesel-diesel, biodiesel-diesel-additive and kerosene-biodiesel blends. Energy Conversion and Management, 84, 164-173.

65. Safari, A., Salamat, R., \& Baik, O.-D. (2018). A review on heat and mass transfer coefficients during deep-fat frying: Determination methods and influencing factors. Journal of Food Engineering, 230, 114-123.

66. Saifuddin N, Chua K. H., Production of ethyl ester (biodiesel) from used frying oil: optimization of transesterification process using microwave irradiation. Malaysian Journal of Chemistry2004;6(1):77-82.

67. Sánchez Hernández, R. (2018). Complete transformation of aluminum waste into zeolite and its use in the removal of pollutants from aqueous solution (doctoral thesis). Universitas Carlos III de Madrid, Madrid, Spain.

68. Sanjib, Kumar, Karmee, Raffel, Dharma, Patria, Carol, Sz,e Ki Lin (2015), Techno-Economic Evaluation of Biodiesel Production from Waste Cooking Oil-A Case Study of Hong Kong, International Journal of Molecular Sciences, 16, 43624371

69. Sanli, H., Alptekin, E. \& Canakci, M. (2019). Production of fuel quality ethyl ester biodiesel: 1. Laboratory-scale optimization of waste frying oil ethanolysis, 2. Pilot-scale production with the optimal reaction conditions. Waste and Biomass Valorization, 10(7), 1889-1898.

70. Sattari, S., Vahabzadeh, F., \& Aghtaei, H. (2015). Performance of loofa-immobilized rhizopus oryzae in the enzymatic production of biodiesel with use of oleic acid in n-hexane medium. Brazilian Journal of Chemical Engineering, 32(2), 367376.

71. Shimada, Y., Watanabe, Y., Sugihara, A. \& Tominaga, Y. (2002). Enzymatic alcoholysis for biodiesel fuel production and application of the reaction to oil processing. Journal of Molecular Catalysis B: Enzymatic, 17(3-5), 133-142.

72. Shuit, S. H., Ong, Y. T., Lee, K. T., Subhash, B. \& Tan, S. H. (2012). Membrane technology as a promising alternative in biodiesel production: A review. Biotechnology Advances, 30(6), 1364-1380.

73. Sunthitikawinsakul, A., \& Sangatith, N. (2012). Study on the quantitative fatty acids correlation of fried vegetable oil for biodiesel with heating value. Procedia Engineering, 32, 219-224.

74. T.D.Tsoutsosa., S.Tournakia., O.Paraíbab., S.D.Kaminarisa (2016), The Used Cooking Oil-to-biodiesel chain in Europe assessment of best practices and environmental performance, Renewable and Sustainable Energy Reviews, 54, 74-83 
75. Varanda, M. G., Pinto, G. \& Martins, F. (2011). Life cycle analysis of biodiesel production. Fuel Processing Technology, 92(5), 1087-1094.

76. Vyas, A. P., Verma, J. L., \& Subrahmanyam, N. (2010). A review on FAME production processes. Fuel, 89(1), 1-9.

77. Wang, Y., Ou, S., Liu, P., Xue F., \& Tang, S. (2006). Comparison of two different processes to synthesize biodiesel by waste cooking oil. Journal of Molecular Catalysis A: Chemical, 252(1-2), 107-112.

78. Wu, L., Wei, T., Lin, Z., Zou, Y., Tong Z., \& Sun, J. (2016). Bentonite-enhanced biodiesel production by NaOH-catalyzed transesterification: Process optimization and kinetics and thermodynamic analysis. Fuel, 182, 920-927.

79. Xia, L. (2017). Using biosolids as a water source in non-catalytic hydrolysis reactions for biofuel production (master's thesis). University of Alberta, Edmonton, Canada.

80. Yin, J.-Z., Xiao, M., \& Song, J.-B. (2008). Biodiesel from soybean oil in supercritical methanol with co-solvent. Energy Conversion and Management, 49(5), 908-912.

81. T.D.Tsoutsosa., S.Tournakia., O.Paraíbab., S.D.Kaminarisa (2016), The Used Cooking Oil-to-biodiesel chain in Europe assessment of best practices and environmental performance, Renewable and Sustainable Energy Reviews, 54, 74-83

82. Yemelyanova, V. S., et al. "Processing fly ash from the thermal power stations for gas emissions purification from sulfur dioxide." International Journal of Mechanical and Production Engineering Research and Development 9.4: 1015-1026.

83. AL-Asady, Amal Kadhim Ghadban. "Optimization of $\alpha$-amylase production from a local isolate of Bacillus licheniformis and characterization of purified enzyme." International Journal of Agricultural Science and Research 6.2: 301-312.

84. Sreejith, K., and C. D. Sebastian. "Molecular evolutionary analysis of paddy pest, Cofana spectra (Distant)(Hemiptera: Cicadellidae) using partial DNA sequence of cytochrome oxidase subunit I (COI) gene." International Journal of Applied and Natural Sciences 3.2: 135-140.

85. Bedjargi, Pruthvi Raj C., and RS Kulkarni. "Sds-Page Analysis and Electron Microscopy of Corpuscles of Stannius Secretion in the Freshwater Fish, Notopterus Notopterus." International Journal of General Medicine and Pharmacy (IJGMP) 3: 1-6. 
